\title{
REMOVAL OF METAL IONS FROM SYNTHETIC WASTEWATER BY ADSORPTION ONTO EUCALYPTUS CAMALDULENIS TREE LEAVES
}

\author{
N. T. ABDEL-GHANI ${ }^{a}$; M. M. HEFNY ${ }^{b}$ AND G. A. EL-CHAGHABY *c \\ a Prof. of inorganic and analytical chemistry, Chemistry Department, Faculty of Science, Cairo University, Giza, Egypt. \\ ${ }^{\mathrm{b}}$ Prof. of physical chemistry, Chemistry Department, Faculty of Science, Cairo University, Giza, Egypt. \\ ${ }^{*}$ Assistant researcher, Agriculture Research Center, Giza, Egypt. \\ (Received: September 9, 2007 - Accepted: May 24, 2006)
}

\begin{abstract}
Eucalyptus Camaldulenis tree leaves were used to study adsorption of several cations $\left(\mathrm{Cu}^{2+}, \mathrm{Zn}^{2+}, \mathrm{Cd}^{2+}\right.$ and $\left.\mathrm{Pb}^{2+}\right)$ from wastewater within various experimental conditions. The dried leaves of Eucalyptus Camaldulenis were used at different adsorbent/metal ion ratios. The influence of $\mathrm{pH}$, contact time, metal concentration, and adsorbent loading weight on the removal process was investigated. Batch adsorption studies were carried out at room temperature. The adsorption efficiencies were found to be $\mathrm{pH}$ dependent, increasing by increasing the $\mathrm{pH}$ in the range from 2.5 to 8.5 . The equilibrium time was attained after $90-120$ minutes and the maximum removal percentage was achieved at an adsorbent loading weight of $1.5 \mathrm{~g} / 50 \mathrm{ml}$ mixed ions solution. The removal order was found to be $\mathrm{Pb}$ (II) $>\mathrm{Cu}$ (II) $>\mathrm{Cd}$ (II) $>\mathrm{Zn}$ (II). This study is one of the first reports of removal of the highly toxic $\mathrm{Cu}^{2+}, \mathrm{Zn}^{2+}, \mathrm{Cd}^{2+}$ and $\mathrm{Pb}^{2+}$ in mixed systems based on the adsorption by natural materials. The potential of application for the treatment of solutions containing these heavy metals in multimetal solutions is indicated.
\end{abstract}

Keyword: Eucalyptus camaldulenis; Lead; Copper; zinc; cadmium; Adsorption; Wastewater; Isotherms.

\section{INTRODUCTION}

The awareness of increasing water pollution implies studies concerning water treatment. Removal of heavy metals from industrial wastewater is of primary importance. The use of natural materials for heavy metals removal is becoming a concern in all countries. Natural materials that are available in large quantities or certain waste from agricultural operations may have potential to be used as low cost adsorbents, as they represent unused resources, widely available and are environmentally friendly ${ }^{1}$.

The application of low-cost natural adsorbents including carbonaceous materials, agricultural products and waste by-products has been investigated in many previous studies ${ }^{2,3}$, which have been recognized as potential alternative to the conventional technologies such as precipitation, ion exchange, solvent extraction and liquid membrane for removal of heavy metals from industrial wastewater because these processes have technical and/or economical constraints.

Several studies have shown that non-living plant biomass materials are effective for the removal of trace metals from the environment ${ }^{4-7}$.

Whereas many previous studies have reported the adsorption of metals by materials of diverse biological origin, these have remained limited to the removal of single metal ion and little information is available for multimetal adsorption systems ${ }^{8,9}$.

Eucalyptus camalulensis tree, an important timber, firewood, shelter belt, and honey tree. It is one of the most widely distributed trees in most of arid and semiarid areas. This kind of tree exists on almost every roadside in Egypt.

Accordingly, this study aimed to investigate the adsorption potential of Eucalyptus camalulensis tree for the removal of $\mathrm{Cu}^{2+}, \mathrm{Zn}^{2+}, \mathrm{Cd}^{2+}$ and $\mathrm{Pb}^{2+}$ from wastewater within various experimental conditions.

\section{MATERIALS AND METHODS}

Eucalyptus camalulensis tree leaves samples were gathered from twigs into clean plastic bags. Washed with DI water and laid flat on a clean table to dry. Dry leaves were grounded with electrical grinder. then stored in clean plastic bags so the samples become ready to use.

Preparation of Synthetic Wastewater

Mixed metal ion solutions of $\mathrm{Cu}^{2+}, \mathrm{Zn}^{2+}, \mathrm{Cd}^{2+}$ and $\mathrm{Pb}^{2+}$ were prepared from Merck - analytical grade stock standards of concentration $1000 \mathrm{mg} / 1$. The synthetic wastewater solutions were then prepared by diluting the stock standard of each. The $\mathrm{pH}$ of the wastewater was adjusted using $1 \mathrm{M} \mathrm{HCl}$ and /or $\mathrm{NaOH}$. The final concentrations of metal ions in the wastewater were analyzed by inductively coupled plasma (ICP-OES) Perkin Elmer Optima2000.

Batch sorption experiments

The sorption studies were carried out at room temperature on a Labline reciprocating shaker using capped tubes, containing $50.0 \mathrm{~mL}$ of the test solution, with a known metal ion concentration. Before mixing with the adsorbent, the $\mathrm{pH}$ of the solution was adjusted with $1 \mathrm{M} \mathrm{HCl}$ and /or $\mathrm{NaOH}$. A known amount of dried untreated plant was added and the tubes were thoroughly mixed, allowing sufficient time for adsorption equilibrium (also examined). The mixtures were filtered through filter paper Whatman no 42 , and the metal ions were determined in the filtrate. The metals content in all the experiment was determined by inductively coupled plasma (ICP- OES) Perkin Elmer Optima2000. Each experiment was repeated two times, and the results are given as averages.

\section{Calculation of cations uptake by Eucalyptus Camaldulenis}

The amount of metal ion removal by the untreated Eucalyptus Camaldulenis biomass during the series of batch investigations was determined using the following equation expressed as:

Removal \% $=\left[\left(\mathrm{C}_{0}-\mathrm{C}_{\mathrm{f}}\right) / \mathrm{C}_{0}\right] \times 100$

Where: $\mathrm{C}_{\mathrm{o}}$ and $\mathrm{C}_{\mathrm{f}}$ are the initial and equilibrium concentration $(\mathrm{mg} / \mathrm{l})$ of metal ions in solution, respectively.

\section{RESULTS AND DISCUSSION}

\section{Eucalyptus camalulensis surface characterization}

The infrared spectrum of Eucalyptus Camaldulenis is given in figure 1 .The spectrum shows strong band at $3413.8 \mathrm{~cm}^{-1}$ attributed to $\mathrm{Si}-\mathrm{OH}$ groups ${ }^{10}$. The two bands at 2920 and $2850.6 \mathrm{~cm}^{-1}$ were assigned to $\mathrm{C}-\mathrm{H}$ stretches of methylene groups on the surface and to chelated H-bridges., while the strong bands at 1639.4 and $1616.2 \mathrm{~cm}^{-1}$ were assigned to stretching $(\mathrm{C}=\mathrm{C})^{10}$. The surface IR-characterization of Eucalyptus Camaldulenis indicated the presence of many functional groups capable of binding to the metal cations.

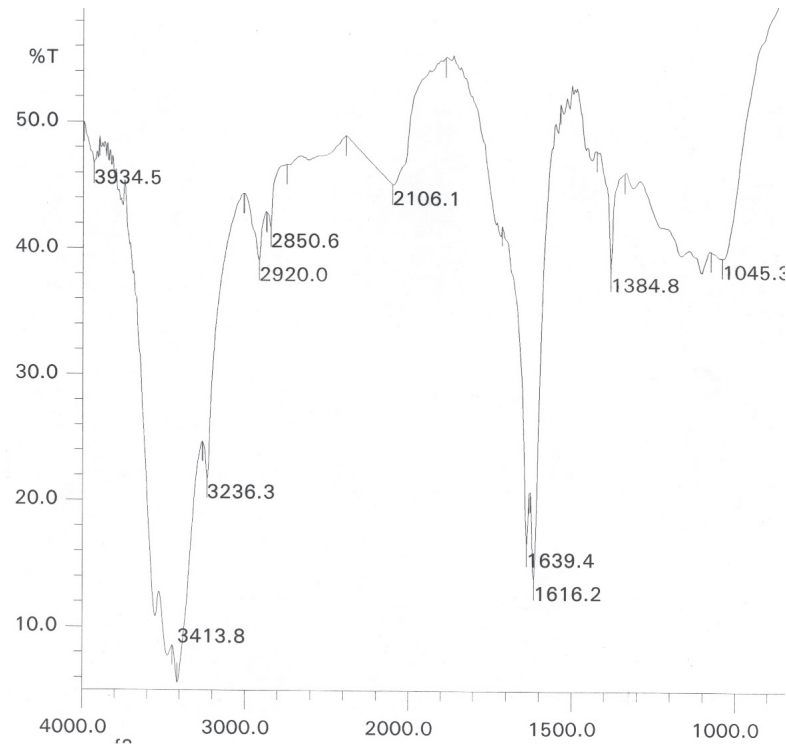

Figure (1): I R spectrum of Eucalyptus Camaldulenis. 
The effect of different operating conditions (contact time, $\mathrm{pH}$, initial ions concentration and adsorbent loading weight) on the removal of $\mathrm{Cu}^{2+}, \mathrm{Zn}^{2+}$, $\mathrm{Cd}^{2+}$ and $\mathrm{Pb}^{2+}$ by adsorption onto Eucalyptus Camaldulenis was investigated. The metals removal studies were illustrated graphically in Figure 2, Figure 3, Figure 4 and Figure 5 which showed that their removals were strongly affected by these different operating conditions.

\section{Effect of contact time}

Figure 2 show the effect of contact time on the uptake of the studied cations onto Eucalyptus Camaldulenis. This was achieved by varying the contact time from 30 to $240 \mathrm{~min}$. in separate experiment runs. Equilibrium contact time was found to be $90 \mathrm{~min}$. in case of $\mathrm{Zn}$ (II) and $\mathrm{Cu}$ (II) ), while the equilibrium in case of $\mathrm{Cd}$ (II) and $\mathrm{Pb}$ (II) was attained after $120 \mathrm{~min}$. The results showed that the removal percentages order at equilibrium was $\mathrm{Pb}(97.18 \%)>\mathrm{Cu}(78.53 \%)$ $>\mathrm{Cd}(45.02 \%)>\mathrm{Zn}(30.63 \%)$. These results are important, as equilibrium time is one of the important parameters for selecting a wastewater treatment system. Where the time consumed for wastewater disposal should be considered.
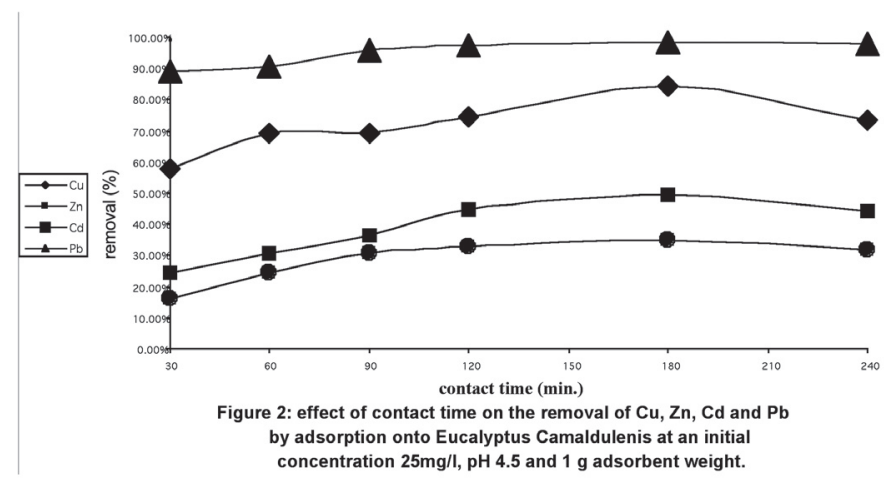

2. The effect of $\mathbf{p H}$

The effect of $\mathrm{pH}$ on adsorption of $\mathrm{Cu}^{2+}, \mathrm{Zn}^{2+}, \mathrm{Cd}^{2+}$ and $\mathrm{Pb}^{2+}$ onto Eucalyptus Camaldulenis was investigated at $\mathrm{pH}$ range $2.5-8.5$. The efficiency of metal ion removal by the adsorbent is affected by the initial $\mathrm{pH}$ of the reaction mixture ${ }^{11}$

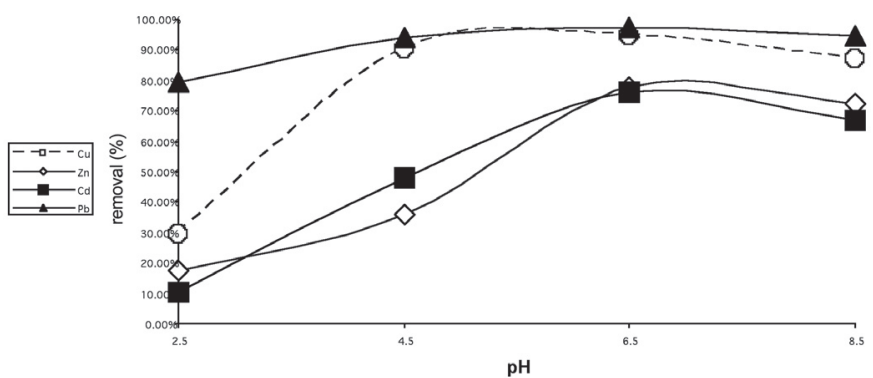

Figure 3. Effect of $\mathrm{pH}$ on metal ions adsorption in their mixed solution by Eucalyptus Camaldulenis.

Figure 3. Effect of $\mathrm{pH}$ on metal ions adsorption in their mixed solution by Eucalyptus Camaldulenis.

The susceptibility of the system to $\mathrm{pH}$ changes may be attributed to the nature of the ions in solution and the nature of the adsorbent used. The lower the $\mathrm{pH}$, the more $\mathrm{H}^{+}$ions competing with copper, zinc , cadmium and lead ions for adsorption sites, thus reducing their adsorption. On the other hand, the higher the $\mathrm{pH}$, the less the $\mathrm{H}^{+}$ions competing with metal ions for adsorption sites, thus increasing their adsorption, which explains the obtained results in figure 3.

The uptake of $\mathrm{Cu}^{2+}, \mathrm{Zn}^{2+}, \mathrm{Cd}^{2+}$ and $\mathrm{Pb}^{2+}$ was dependent on $\mathrm{pH}$, where optimal metal removal efficiency occurred at $\mathrm{pH}$ range from 4.5 to 6.5 and then declining at higher $\mathrm{pH}$. This may be explained by the fact that in a higher $\mathrm{pH}$ range, existence of counter ions might result in lower efficiency of adsorption ${ }^{12}$.

3. The effect of initial metal ions concentration

The effect of initial metal concentration on the adsorption efficiency of
Eucalyptus Camaldulenis is shown in Figure.4. Adsorption experiments were carried out at different initial $\mathrm{Cu}^{2+}, \mathrm{Zn}^{2+}, \mathrm{Cd}^{2+}$ and $\mathrm{Pb}^{2+}$ concentrations ranging from 5 to $50 \mathrm{mg} / \mathrm{l}$ in mixed metal ions solution. The adsorption efficiency decreased with the increasing of the initial concentration of the metal ions. These results may be explained on the basis that the increase in the number of ions competing for the available binding sites and also because of the lack of active sites on the adsorbent at higher concentrations. Therefore, more metal ions were left unadsorbed in solution at higher concentration levels ${ }^{13}$.

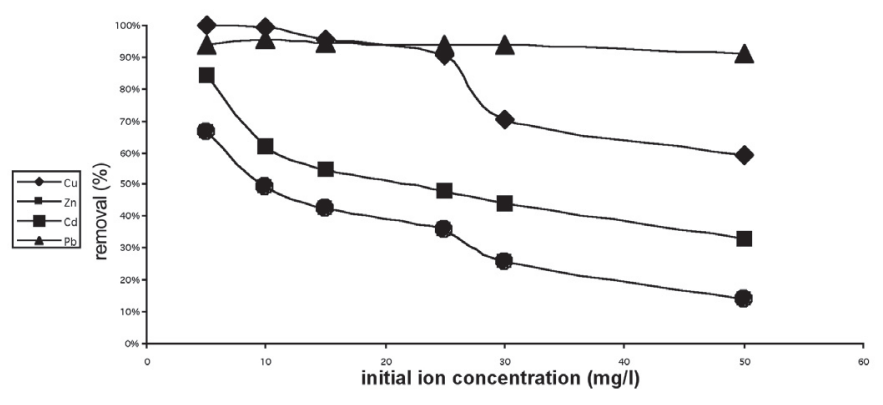

Figure 4. The effect of variation in initial metal ions concentrations onto their adsorption using Eucalyptus

\section{The effect of adsorbent loading weight}

The effect of adsorbent loading weight on the removal of cations by Eucalyptus Camaldulenis was investigated. The adsorbent loading weight was varied from 0.25 to $2.0 \mathrm{~g} / 50 \mathrm{~mL}$ of mixture metal ions solution containing $25 \mathrm{mg} / 1$ of each of the investigated metals.

The effect of Eucalyptus Camaldulenis weight is graphically presented in figure 5. It can easily be inferred that the percent removal of metal ions increases with increasing weight of Eucalyptus Camaldulenis. This is due to the greater availability of the exchangeable sites or surface area at higher dose of the adsorbent . these results are in agreement with previous studies on many other adsorbents ${ }^{12,14,15}$

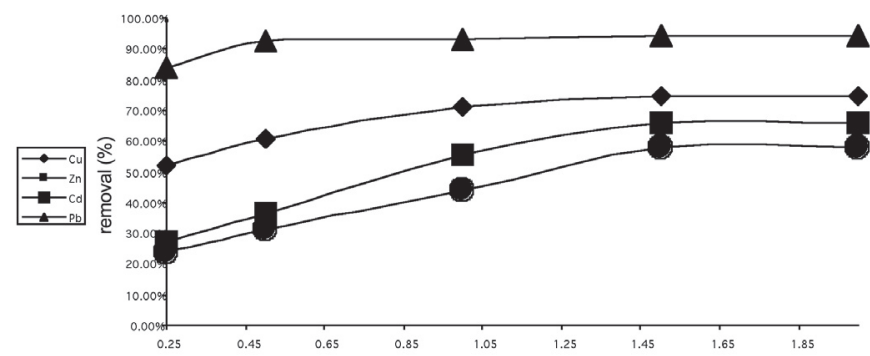

adsorbent weight (g)

Figure 5. Effect of Eucalyptus Camaldulenis loading weight on metal ion adsorption in a mixed metal ion solution.

The maximum removal of the studied cations was attained at an adsorbent dose of $1.5 \mathrm{~g}$ with no further increase in the removal percentage at $2 \mathrm{~g}$ of adsorbent.

Isothermal studies

The experimental data for the uptake of metal ions by Eucalyptus Camaldulenis were processed in accordance with the three of the most widely used adsorption isotherms: Langmuir, Freundlich and Temkin isotherms. The data were found to best fit the Temkin isotherm model assuming chemical adsorption between metal ions and Eucalyptus Camaldulenis.

The Temkin isotherm model is given by the following equation:

$\mathrm{X}=\mathrm{a}+\mathrm{b} \ln \mathrm{C}$

Where $\mathrm{C}=$ Concentration of adsorbate in solution at equilibrium $(\mathrm{mg} / \mathrm{L})$.

$\mathrm{X}=$ Amount of metal adsorbed per unit weight of adsorbent $(\mathrm{mg} / \mathrm{g})$

$\mathrm{a} \& \mathrm{~b}$ are constants related to adsorption capacity and intensity of adsorption.

Figure (6) shows a plot of $\mathrm{X}$ against $\ln \mathrm{C}$ for $\mathrm{Cd}$ (II) sorption onto Eucalyptus Camaldulenis as a representative example for the application of Temkin model. the plot gives a straight line with slope representing the Temkin constant (b). 
$y=3.3467 x+3.4027$

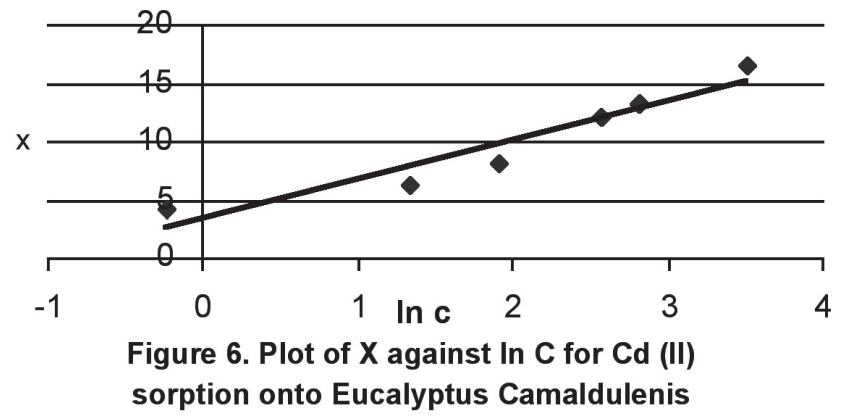

Figure 6. Plot of $\mathrm{X}$ against $\ln \mathrm{C}$ for $\mathrm{Cd}$ (II) sorption onto Eucalyptus Camaldulenis

The values of Temkin isotherm constant (b) were found to be 18.805 , 2.9602, 3.4027 and 20.401 for the adsorption of $\mathrm{Cu}^{2+}, \mathrm{Zn}^{2+}, \mathrm{Cd}^{2+}$ and $\mathrm{Pb}^{2+}$ onto Eucalyptus Camaldulenis, respectively. The Temkin isotherm fitted the present data because it takes into account the occupation of the more energetic adsorption sites at first. For natural unmodified materials such as Eucalyptus Camaldulenis it is highly probable that their adsorption sites are energetically non-equivalent ${ }^{16}$.

\section{CONCLUSION}

The results presented in this study, showed that dried leaves of Eucalyptus Camaldulenis can efficiently remove $\mathrm{Cu}^{2+}, \mathrm{Zn}^{2+}, \mathrm{Cd}^{2+}$ and $\mathrm{Pb}^{2+}$ present in aqueous solutions. The removal percentages of the studied cations were dependent on the weight of the adsorbent, the initial ions concentration, contact time and $\mathrm{pH}$ of the solution. Metal sorption is $\mathrm{pH}$ dependent and maximum sorption for $\mathrm{Cu}^{2+}, \mathrm{Zn}^{2+}, \mathrm{Cd}^{2+}$ and $\mathrm{Pb}^{2+}$ ions was found to occur at a $\mathrm{pH} 4.5$ -6.5 and the equilibrium conditions were attained after $90 \mathrm{~min}$. in case of $\mathrm{Zn}$ (II) and $\mathrm{Cu}$ (II) and at $120 \mathrm{~min}$. in case of $\mathrm{Cd}$ (II) and $\mathrm{Pb}$ (II) . The Temkin isotherm was found to well represent the obtained sorption data .Eucalyptus Camaldulenis is found to be a good adsorbent for the removal of metal cations from mixed metal ions solution, representing an effective and environmentally clean utilization of waste matter.

\section{REFERENCES}

1.- J.R. Deans, and B.G Dixon, Water Research, vol. 26 (4), 469 (1992).

2.- C. Nguyen and D. D. Do. Carbon 39, 1327 (2001).

3.- K.K. Singha, , R. Rastogib and S.H. Hasan; J. Hazard. Mater. 121 (1-3), $51(2005)$

4.- A.S.Mofa, Science 269, 302 (1995).

5.- J.R. Lujan, D.W. Damall, P.C. Stark, G.D. Rayson and J.L.GardeaTorresdey Solvent Extr. Ion Exch. 12803 (1994).

6.- J.L. Gardea-Torresdey, K.J. Tiemann, J.H. Gonzalez, J.A. Henning and M.S. Townsend, J. Hazard Mater. 5729 (1996).

7.- $\quad$ A.A. Abia, M. Jnr Horsfall and O. J. Didi, Appl. Sci Environ. Mgt. 689 (2002).

8.- $\quad$ S.F. Al-Asheh, R. Banat, Z. Al-Omari and Duvnjak, Chemosphere 41, p. 659,(2000).

9.- Y. Sag, B. Akcael and T. Kutsal, Process Biochem., 3735 (2001).

10.- B. Stuart, Modern Infrared spectroscopy. John Wiley \& sons. Inc. (1996).

11.- Michael Horsfall Jnr. Electronic Journal of Biotechnology, 7, 3 (2004).

12.- Bin Yu, Y. Zhang, Alka Shukla, Shyam S. Shukla and Kenneth L. Dorris, J. Hazard. Mater, 84 (1), 83, (2001).

13.- K.Anoop Krishnan and T. S Anirudhan. Water SA, vol 29 , no.2,(2003).

14.- M.Ajmal ;Khan,A.H.;Ahmed-Sh and A. Ahmad, Water-research. 32 (10), 3085 ( 1998).

15.- M. Dakiky, M. Khamis, A. Manassra and M. Mer'eb, Advances in Environmental Research V 6, Issue 4, Pages 533-540,(2002).

16.- K.W.Kolasniski. Surface Science, Wiley, Chister, UK(2001). 